\title{
Perbandingan Kadar Ureum dan Kreatinin Serum Masyarakat Terpapar dengan Tidak Terpapar Emisi Pabrik PT. Semen Padang
}

\author{
Mira Purwinanty ${ }^{1}$, Rismawati Yaswir ${ }^{2}$, Efrida ${ }^{3}$
}

\begin{abstract}
Abstrak
Emisi pabrik semen tidak hanya berisiko pada pekerja di pabrik semen, tetapi berdampak pada penduduk yang tinggal di daerah sekitarnya. Penelitian epidemiologi menunjukkan bahwa konsentrasi PM (particulate matter) di udara memiliki korelasi dengan tingkat mortalitas dan morbiditas. Emisi pabrik semen terutama particulate matter bersifat nefrotoksik. Penelitian ini bertujuan mengetahui perbandingan kadar ureum dan kreatinin masyarakat yang terpapar dengan tidak terpapar emisi pabrik semen. Penelitian ini merupakan penelitian analitik dengan rancangan potong lintang terhadap 152 subjek terpapar dan 169 subjek tidak terpapar dari bulan Juni 2015-September 2016. Parameter yang diperiksa adalah ureum menggunakan metode enzimatik (glutamat dehidrogenase) dan pemeriksaan kreatinin menggunakan metode kolorimetri (Jaffe). Hasil pemeriksaan dianalisis menggunakan uji $t$, bermakna bila $p$ $<0,05$. Subjek penelitian daerah terpapar terdiri dari laki-laki 33 orang $(21,7 \%)$ dan perempuan 119 orang $(78,3 \%)$ dengan rentang umur 19-75 tahun sedangkan daerah tidak terpapar terdiri dari laki-laki 18 orang $(10,7 \%)$ dan perempuan 151 orang $(89,3 \%)$ dengan rentang umur 20-80 tahun. Kadar rerata ureum daerah terpapar 17,53(6,7) $\mathrm{mg} / \mathrm{dL}$ dan kadar rerata ureum daerah tidak terpapar $17,22(5,1) \mathrm{mg} / \mathrm{dL}$, hasil statistik tidak menunjukkan perbedaan bermakna $(p<0,05)$. Kadar rerata kreatinin daerah terpapar $0,85(0,3) \mathrm{mg} / \mathrm{dL}$ dan kadar rerata kreatinin daerah tidak terpapar $0,79(0,2) \mathrm{mg} / \mathrm{dL}$, hasil statistik menunjukkan perbedaan bermakna $(\mathrm{p}<0,05)$. Kadar kreatinin pada masyarakat terpapar emisi pabrik PT. Semen Padang lebih tinggi tetapi masih dalam batas normal sedangkan kadar ureum tidak menunjukkan perbedaan. Penelitian kohort prospektif diperlukan untuk mendapatkan gambaran perjalanan penyakit berdasarkan lama paparan.
\end{abstract}

Kata kunci: Emisi pabrik semen, kreatinin, ureum

\begin{abstract}
Cement factory emission not only affect the factory workers but also affected people who live around the cement factory. Epidemiologycal studies showed the correlation of morbidity and mortality with the concentration of particulate matter (PM) in the air. Cement factory emission, especially particulate matter is nefrotoxic. The aim of this study is to compare ureum and creatinine level in people exposed and unexposed to cement factory emission. This was an analytical study with cross-sectional design of one hundred fifty two exposed subject and one hundred sixty nine unexposed subject from June 2015 until September 2016. This study investigated ureum and creatinin level, which was enzymatic (glutamate dehydrogenase) for ureum level and colorimetric method (Jaffe) for creatinine level. Test result were analyzed using t-test, significant if $p<0,05$. Subject in exposed area are thirty three males $(21,7 \%)$ and one hundred nineteen females (78,3\%), age was nineteen until seventy five years old, in unexposed area are 18 males (10,7\%) and 151 females (89,3\%) with age 20-80 years old. The mean level of ureum in exposed people $17,53(6,7) \mathrm{mg} / \mathrm{dL}$, and in unexposed people was $17,22(5,1) \mathrm{mg} / \mathrm{dL}$, there were no significant different $(p>0,05$.) The mean level of creatinine in exposed people 0,85(0,3) $\mathrm{mg} / \mathrm{dL}$, and in unexposed people was 0,79(0,2) $\mathrm{mg} / \mathrm{dL}$, there were significant different $(p<0,05)$. Creatinine level was higher in exposed area but the level was in normal range, and ureum level was no significant differences. Further studies using prospective (cohort) design are needed to figure the clinical history.
\end{abstract}

Keywords: Cement factory emission, creatinine, ureum

Affiliasi penulis : ${ }^{1}$ Program Pendidikan Dokter Spesialis Patologi Klinik Fakultas Kedokteran Universitas Andalas/ Rumah Sakit Umum Pusat Dr. M. Djamil, Padang, ${ }^{2,3}$ Bagian Patologi Klinik, Fakultas Kedokteran Universitas Andalas/Rumah Sakit Umum Pusat Dr. M. Djamil, Padang

Korespondensi : Jl. Perintis Kemerdekaan Padang, email pdspatklin_padang@yahoo.com

\section{PENDAHULUAN}

Sektor produk mineral seperti penambangan bahan baku semen dan industri semen adalah salah satu penyumbang terpenting emisi PM (particulate matter). ${ }^{1}$ Emisi PM dari sumber terbuka (fugitive dust emission) berupa aktivitas penambangan, pengepakan, transportasi semen, maupun melalui aliran cerobong asap (point-source emission) tidak hanya berisiko pada para pekerja di pabrik semen, tetapi juga berdampak pada penduduk yang tinggal di daerah sekitarnya. ${ }^{2}$

Debu semen diklasifikasikan menjadi 2 (dua) jenis utama, semen alam dan buatan (Portland) semen. Semen Portland adalah campuran dari kalsium oksida (62\%-66\%), silikon oksida (19\%-22\%), aluminium trioksida (4\%-8\%), oksida besi (2\%-5\%) dan magnesium oksida (1\%-2\%). Debu semen selain 
mengakibatkan kelainan fungsi pernapasan, juga mengakibatkan kelainan organ ekstra pulmoner seperti jantung dan ginjal. Penelitian epidemiologi menyatakan tingkat paparan tinggi logam berat seperti timah $(\mathrm{Pb})$, merkuri $(\mathrm{Hg})$ dan cadmium $(\mathrm{Cd})$ bersifat nefrotoksik, sehingga hal ini berpengaruh terhadap fungsi ginjal. Salah satu parameter yang banyak digunakan untuk mengetahui fungsi ginjal adalah ureum dan kreatinin. ${ }^{3}$

Paparan yang lama terhadap polusi udara berpengaruh terhadap kerusakan ginjal. Ginjal merupakan target organ dari berbagai substansi toksik, dan efek ginjal sering digunakan sebagai indikator prediktor awal terhadap paparan logam berat pada polusi udara. ${ }^{4,5}$

Mekanisme penyebab kelainan ginjal akibat paparan debu semen belum diketahui secara jelas. Beberapa mekanisme yang dapat menyebabkan kerusakan ginjal, diantaranya efek langsung partikel toksik. Efek langsung yaitu PM yang mengandung debu silika dan logam berat sebagai toxic agent pada ginjal merupakan faktor yang menimbulkan kerusakan ginjal, partikel toksik ini akan mengendap pada parenkim ginjal kemudian akan menyebabkan kerusakan ginjal. Salah satu parameter yang dapat diukur dalam penilaian fungsi ginjal adalah kadar ureum dan kreatinin. $5,6,7$

Penelitian tentang efek emisi pabrik semen terhadap fungsi ginjal terutama ureum dan kreatinin masih sedikit yang ditemukan. Penelitian tentang efek emisi pabrik semen yang ditemukan saat ini lebih banyak dilakukan terhadap pekerja pabrik, sedangkan penelitian efek emisi pabrik semen terhadap fungsi ginjal masyarakat sekitar pabrik semen masih sedikit dilaporkan. Penelitian tentang efek emisi pabrik terutama silika dan logam berat terhadap kadar ureum dan kreatinin pada pekerja pabrik semen telah banyak dilaporkan. Penelitian pada pekerja pabrik semen di Irak dan Arab Saudi menunjukkan peningkatan signifikan ureum dan kreatinin yang merupakan efek nefrotoksik akibat paparan debu silika dan logam berat. 8,9

Berdasarkan hal tersebut peneliti tertarik untuk mengetahui perbedaan fungsi ginjal melalui pemeriksaan kadar ureum dan kreatinin serum pada masyarakat di daerah terpapar dengan yang tidak terpapar emisi pabrik PT. Semen Padang.

Penelitian ini bertujuan untuk mengetahui perbedaan kadar ureum dan kreatinin serum masyarakat terpapar dengan tidak terpapar emisi pabrik PT. Semen Padang.

\section{METODE}

Penelitian ini adalah penelitian analitik dengan rancangan potong lintang, dilakukan di Fakultas Kedokteran Universitas Andalas Limau Manis dan Laboratorium Sentral RSUP Dr. M. Djamil Padang mulai Juni 2015 sampai September 2016. Populasi penduduk yang terpapar dengan emisi pabrik Semen Padang adalah penduduk dengan jarak tempat tinggal radius $\leq 5 \mathrm{~km}$ dari lokasi pabrik dan yang tidak terpapar dengan jarak tempat tinggal radius $\geq 10 \mathrm{~km}$ dari lokasi pabrik. Sampel penelitian adalah bagian dari populasi yang memenuhi kriteria inklusi dan eksklusi dengan jumlah sampel 152 untuk daerah terpapar dan 169 untuk daerah tidak terpapar.

Kriteria inklusi adalah masyarakat bermukim minimal 2 tahun di daerah sekitar pabrik PT. Semen Padang, berusia $\geq 18$ tahun, dan bersedia ikut penelitian. Kriteria eksklusi adalah penduduk dengan kriteria IMT (indeks massa tubuh) underweight, riwayat hipertensi, penyakit ginjal, dan diabetes melitus yang diperoleh melalui anamnesis. Tes fungsi ginjal yang diperiksa adalah ureum dan kreatinin. Metode yang digunakan untuk pemeriksaan ureum adalah enzimatik (glutamat dehidrogenase) dan pemeriksaan kreatinin menggunakan metode kolorimetri (Jaffe).

Data penelitian ditampilkan dalam bentuk tabel distribusi frekuensi. Data dianalisis dengan metode statistik uji t. Hasil dianggap bermakna bila $p$ $<0,05$.

\section{HASIL DAN PEMBAHASAN}

Telah dilakukan penelitian terhadap 152 subjek terpapar dan 169 subjek tidak terpapar dengan rentang umur 19-80 tahun. Karakteristik subjek dapat dilihat pada Tabel 1.

Berdasarkan tabel 1, jenis kelamin perempuan lebih banyak dari laki-laki pada kedua kelompok. Hal tersebut disebabkan distribusi penduduk yang bermukim sekitar pabrik PT. Semen Padang sebagian besar adalah perempuan. Berdasarkan usia didapatkan subjek daerah terpapar lebih muda dibandingkan subjek tidak terpapar.

\begin{tabular}{|c|c|c|c|c|}
\hline \multirow[t]{2}{*}{ Variabel } & \multicolumn{2}{|c|}{$\begin{array}{l}\text { Terpapar } \\
(n=152)\end{array}$} & \multicolumn{2}{|c|}{$\begin{array}{l}\text { Tidak terpapar } \\
\quad(n=169)\end{array}$} \\
\hline & $\mathrm{n}(\%)$ & $X(S D)$ & $\mathrm{n}(\%)$ & $X(S D)$ \\
\hline \multicolumn{5}{|l|}{ Jenis Kelamin } \\
\hline - Laki-laki & $\begin{array}{l}33 \\
(21,7)\end{array}$ & & $\begin{array}{l}18 \\
(10,7)\end{array}$ & \\
\hline - Perempuan & $\begin{array}{l}119 \\
(78,3)\end{array}$ & & $\begin{array}{l}151 \\
(89,3)\end{array}$ & \\
\hline Umur (tahun) & & $\begin{array}{l}45,3 \\
(12,9)\end{array}$ & & $\begin{array}{l}47,6 \\
(13,3)\end{array}$ \\
\hline IMT $\left(\mathrm{kg} / \mathrm{m}^{2}\right)$ & & $\begin{array}{l}24,5 \\
(4,5)\end{array}$ & & $\begin{array}{l}24,9 \\
(5,0)\end{array}$ \\
\hline
\end{tabular}
ditemukan perbedaan yang bermakna antara daerah terpapar dan tidak terpapar $(p>0,05)$.

Kadar rerata ureum dan kreatinin, pada kelompok yang terpapar dan tidak terpapar dapat dilihat pada Tabel 2.

\begin{tabular}{lccc}
\hline & $\begin{array}{c}\text { Terpapar } \\
\text { X(SD) }\end{array}$ & $\begin{array}{c}\text { Tidak } \\
\text { Terpapar } \\
\text { X(SD) }\end{array}$ & $\mathrm{p}$ \\
\hline $\begin{array}{l}\text { Ureum } \\
\text { (mg/dL) }\end{array}$ & $17,53(6,7)$ & $17,22(5,1)$ & 0,67 \\
$\begin{array}{l}\text { Kreatinin } \\
(\mathrm{mg} / \mathrm{dL})\end{array}$ & $0,85(0,3)$ & $0,79(0,2)$ & 0,03 \\
\hline
\end{tabular}


Berdasarkan tabel 2, kadar rerata ureum dan kreatinin lebih tinggi pada daerah terpapar dibandingkan daerah tidak terpapar. Kadar ureum menunjukkan perbedaan tidak bermakna $(p>0,05)$. Kadar kreatinin menunjukkan perbedaan yang bermakna $(p<0,05)$.

Penelitian ini mendapatkan tidak adanya perbedaan yang bermakna kadar ureum pada daerah yang terpapar emisi pabrik semen dengan daerah yang tidak terpapar. Kadar kreatinin menunjukkan perbedaan yang bermakna. Penelitian ini sesuai dengan penelitian lainnya yang mendapatkan peningkatan kreatinin yang bermakna dibandingkan kontrol. 8,9

Penelitian lainnya memperlihatkan hasil yang berbeda yaitu terdapat peningkatan bermakna ureum dan kreatinin yang menggunakan subjek pekerja pabrik semen dengan intensitas paparan 8 jam dengan nilai ambang $\mathrm{PM}>25 \mu \mathrm{g} / \mathrm{m}^{3}$ per hari. Perbedaan ini disebabkan karena perbedaan lamanya paparan emisi pabrik semen dan kadar paparan PM dalam 24 jam pada subjek penelitian ini. Berdasarkan hasil pengukuran 24 jam kadar PM di udara pada kedua kelompok berada dibawah nilai ambang yaitu $<25 \mu \mathrm{g} / \mathrm{m}^{3}$. Hal ini sesuai dengan ketetapan ambang konsentrasi PM untuk rerata 24 jam yang baru dapat menimbulkan gangguan fungsi organ adalah diatas $25 \mu \mathrm{g} / \mathrm{m}^{3} .9,10$

Indikator terbaik yang digunakan untuk menilai fungsi ginjal secara keseluruhan pada individu normal maupun dengan penyakit adalah LFG (laju filtrasi glomerulus). Penurunan LFG mendahului kegagalan fungsi ginjal pada semua bentuk perjalanan penyakitnya. Metode baku emas yang digunakan untuk penilaian LFG adalah inulin. Penggunaan inulin sebagai baku emas penilaian LFG memiliki banyak keterbatasan, seperti teknik pengumpulan sampel dan pengerjaan yang sulit, waktu pengerjaan yang lama serta biaya yang mahal. Hal tersebut menjadi dasar pertimbangan untuk melakukan penilaian fungsi ginjal melalui pemeriksaan ureum dan kreatinin. ${ }^{11,12}$

Kelainan ginjal akan berhubungan dengan peningkatan urea dalam darah yang dikenal dengan uremia, proses ini berlangsung kronik dan keadaan ini biasa terjadi pada kerusakan nefron yang cukup luas. Peningkatan kadar kreatinin serum baru terjadi setelah LFG menurun setengah dari nilai normal atau ginjal kehilangan $50 \%$ fungsinya. ${ }^{11,12}$

Parameter ureum dan kreatinin yang diperiksa dalam penelitian ini masih dalam batas normal. Hal ini disebabkan karena kadar rerata 24 jam PM di udara masih berada dibawah nilai ambang yaitu $<25 \mu \mathrm{g} / \mathrm{m}^{3}$, sehingga pengaruh efek emisi pabrik terhadap fungsi ginjal terutama kadar ureum dan kreatinin belum terlihat. Kadar kreatinin pada daerah terpapar lebih tinggi dibandingkan daerah tidak terpapar, hal ini disebabkan populasi laki-laki pada daerah terpapar lebih banyak sehingga memengaruhi hasil pemeriksaan kreatinin. Variabilitas produksi kreatinin pada individu dipengaruhi oleh banyak faktor yaitu massa otot, diet, usia, dan jenis kelamin. Perbedaan faktor tersebut dapat menyebabkan fungsi ginjal yang jauh berbeda. ${ }^{11,12}$

\section{SIMPULAN}

Kadar kreatinin pada masyarakat terpapar emisi pabrik PT. Semen Padang lebih tinggi dibandingkan daerah tidak terpapar tetapi masih dalam batas normal, sedangkan kadar ureum tidak menunjukkan perbedaan.

\section{SARAN}

Penelitian tentang efek emisi pabrik semen terhadap fungsi ginjal terutama ureum dan kreatinin pada masyarakat sekitar pabrik masih jarang ditemukan, oleh karena itu diperlukan penelitian kohort prospektif untuk mendapatkan gambaran perjalanan penyakit berdasarkan lama paparan.

\section{DAFTAR PUSTAKA}

1. Lei $Y$, Zhang Q, Nielsen C. An Inventory of Primary Air Pollutants and $\mathrm{CO} 2$ Emissions from Cement Production in China, 1990-2020. Atmos Environ (Internet). 2011 (diunduh Feb 2015);45(1):147-154.

2. Kakkooei $H$, Kakouei AK, Poornajaf A, Ferasaty F. Variability in Total Dust Exposure in a Cement Factory. Industrial Health (internet) 2012 (diunduh Feb 2015); 50:64-68.

3. Kim NH, Hyun YY, Lee KB, Chang $Y$, Rhu S, Oh $\mathrm{KH}$, et al. Environmental Heavy Metal Exposure and Chronic Kidney Disease in the General Population. J Korean Med Sci. 2015 (diunduh April 2015);30(4):507.

4. Elmore SA, Boorman GA. Environmental Toxicologic Pathology and Human Health. In: Haschek WM, Rouseaux CG, Wallig MA. Handbook of Toxicologic Pathology, 3rd ed. USA: Academic Press; 2013. p 1029-1049.

5. Salhen KS. Assessment of Oxidative Stress, Haematological, Kidney and Liver Function Parameters of Libyan Cement Factory Workers. Journal of American Science. 2014 (diunduh Feb 2015);10(5):58-65.

6. Ghahramani N. Silica Nephropathy. Journal of Occupational and Environmental Medicine. 2010 (diunduh Feb 2015);1(3):108-115

7. Vupputuri S, Parks CG, Sandler DP. Occupational Silica Exposures and Chronic Kidney Disease. Ren fail. 2012 (diunduh Apr 2015);34(1):40-46.

8. Rubinstein S, Wang C, Qu W. Occupational Risk and Chronic Kidney Disease: a Population-Based Study in the United States Adult Population. International Journal of Nephrology and Renovascular Disease. 2013 (diunduh Apr 2015); 6:53-59.

9. Sameen AM. Study Effect of Cement Dust Exposure on Liver and Kidney Parameters in Some Cement Field workers in Al-Ramadi City. J of University of Anbar for Pure Science. 2013 (diunduh Apr 2015):7(2):1-5. 
10. Alhayali A, Alharbawi MK, Ali SY. Effect of Cement Pollution on Creatinine and Blood Urea in Hamam Al Alil Factory Workers. College of Basic Education Researchers Journal. 2010 (diunduh Apr 2015);11(3):787-795.

11. Lamb E, Newman DJ, Price CP. Kidney Function Test. In: Burtis CA, Ashwood ER, Bruns DE. Tietz Textbook of Clinical Chemistry And Moleculer Diagnostic 5th ed. Missouri: Elsevier Saunders; 2012:797-828.

12. Imai E, Yasuda Y, Makino H. Japan Association of Chronic Kidney Disease Initiative (J-CKD). Japanese Association of Medical Science. 2011 (diunduh Apr 2015);54(6):403-405. 